\title{
Friction in War: The Effects of Climate, Disease, and Morale at the Battle of Labadieville
}

\author{
Stephen S. Michot \\ Nicholls State University
}

\begin{abstract}
This article reviews and applies the theories of two of the most prominent post-Napoleonic writers, the Baron de Jomini and Carl von Clausewitz, to an obscure yet relevant battle in the American Civil War. Civil War commanders were trained in the Napoleonic art of war, and attempted on the battlefield to execute the basic principles of warfare as outlined by Jomini. Despite the best plans and executions of strategy and tactics, frictions in war, as discussed by von Clausewitz, tend to disrupt preparations and affect battle outcomes. The south Louisiana 1862 Battle of Labadieville serves as an ideal case study for fostering this thesis.
\end{abstract}

Keywords: Baron de Jomini, Battle of Labadieville, Carl von Clausewitz, frictions in war, Lafourche region

The American Civil War has been viewed as the last Napoleonic war. Two of the most renowned military writers of the post-Napoleonic period were the Baron de Jomini and Carl von Clausewitz. Both Jomini and Clausewitz studied the Napoleonic wars and based their theories upon them. The American Civil War, thus, can be viewed as a proving ground for such theories. This paper introduces a relatively small engagement in a remote corner of the American conflict to illustrate and analyze Jominian and Clausewitzian theory and practice. In its simplicity, the 1862 Battle of Labadieville is ideal. Both commanders and their armies were trained in the Napoleonic art of war, and attempted for the most part to implement Napoleonic strategy and tactics. An analysis of this battle serves the purpose of bringing attention to a grossly neglected, yet significant, theater of the war, while providing a refreshing approach to the study of war, in particular, the application of Clausewitz's theory on friction in war.

Carl von Clausewitz in his seminal work Vom Krieg discussed the unpredictable nature of warfare. Despite the best laid plans, the preciseness of calculations, and the adherence to preparations, things tend to go awry. Minor incidents combine to lower overall performance. "War is the province of chance and uncertainty," he wrote. ${ }^{1}$ What he referred to as friction retards or obstructs intended courses of action. The effect of friction in war can lead to defeat in battle. These so-called frictions vary and can affect outcomes to different degrees; however, three of them — climate, disease, and morale-were prevalent enough at the 27 October 1862 American Civil War Battle of Labadieville to influence results. ${ }^{2}$

Armies approach battle attempting to follow a strict set of rules. For Civil War combatants, this science or art of war was based on Napoleonic strategy and tactics. Strategically, Napoleon practiced two grand maneuvers. One strategy was to seek interior lines by maneuvering á la centre between two halves of a divided

\footnotetext{
Stephen S. Michot is an associate professor of history at Nicholls State University.

${ }^{1}$ Leonard, A Short Guide to Clausewitz On War, 73 (quote).

${ }^{2}$ Clausewitz, On War, 119.
} 
enemy force. A second strategy was to place his army across the enemy's line of supply/retreat/communication by maneuvering sur les derrieres. ${ }^{3}$ Tactically, a commander should seize the initiative; achieve surprise while maintaining security; mass his forces through maneuver against a critical point in the enemy's line while effecting an economy of force-a holding force against other sectors using minimum numbers; preserving command and control over one's forces, and keeping a reserve force. ${ }^{4}$ One of the preferred Napoleonic tactical maneuvers was the flanking movement or envelopment of the enemy's flanks. ${ }^{5}$ Both Clausewitz and the Baron de Jomini, two of the most influential students of Napoleonic warfare, stressed simplicity in battle. "The more simple a ... maneuver is," Jomini postulated, "the more sure of success will it be."6

Civil War commanders trained in the art of war practiced Napoleon's maxims. Paddy Griffith, in Battle Tactics of the Civil War argued that early French studies on the Napoleonic wars were "a central influence in the military education" of many Civil War commanders. A study of the actions on the battlefield seems to prove, he wrote, that rather than "being the first modern war, (the Civil War) was in fact the last Napoleonic war." Michael Howard in his work on Clausewitz stated that outside of Germany, Jomini was "the most influential writer on military affairs ... until the end of the nineteenth century." ${ }^{8}$ During the Civil War, even the translators of Jomini from French into English at the United States Military Academy at West Point emphasized in the preface to Jomini's The Art of War that "an acquaintance with the campaigns of Napoleon I is quite important, as they are constantly referred to by Jomini and by all other recent writers on the military art." 9

There were three basic combat arms during the Napoleonic and Civil War eras: infantry, cavalry, and artillery. Infantry was the principle centerpiece of an army. Individual soldiers were armed with muzzle-loading smoothbore and rifled muskets. During the Civil War, the infantry foot soldier usually deployed into two lines which was the most effective formation for massed volley fire, and command and control of the troops. ${ }^{10}$ From these lines, skirmishers were deployed to the front to screen the main force while probing for the enemy. The cavalry arm was noted for its horse mobility. Cavalrymen were usually armed with pistol and sword, but could also be equipped with shotguns and carbines. Cavalry could fight mounted or dismounted, and was best used in reconnaissance, screening, envelopments, and pursuits. Field artillery of the Civil War era usually employed smoothbore and rifled cannons of a 12-pounder caliber, although howitzers and cannons of different calibers were also used. Artillery fought in batteries of two or more guns; and could fire solid shot, explosive shells, or canister. There were also a number of combat support services including engineers, logistics, and signal units, among other types that proved important to commanders. In order to be effective on the battlefield, a commander had to apply these military assets in such a way as to be supportive of one another, or acting in conjunction with the other combat arms in what military historians refer to as combined arms. ${ }^{11}$

The two opposing commanders at the Battle of Labadieville were Brigadier General Godfrey Weitzel and Brigadier General Alfred Mouton. Both of these men were West Point graduates. Both were learned in the

\footnotetext{
3 Bruce, et al., Fighting Techniques of the Napoleonic Age, 1792-1815, 28.

4 Ross, "Napoleon and Maneuver Warfare" 2; Preston, et al., Men in Arms, 123, 167; Jomini, The Art of War, 164-165, 185.

5 Delbruck, The Dawn of Modern Warfare, 433.

6 Jomini, The Art of War, 179 (quote); Clausewitz, On War, 34.

7 Griffith, Battle Tactics of the Civil War, 10-11 (quote).

8 Howard, Clausewitz, 24.

9 Jomini, The Art of War, 6 (quote). For a more in-depth study see Griffith, Battle Tactics of the Civil War, 189-192.

${ }^{10}$ Hardee, Hardee's Rifle and Light Infantry Tactics (1861), Title First, Article First, \#8.

11 Griffith, Battle in the Civil War, 6-43; Griffith, Battle Tactics of the Civil War, 137-188.
} 
Napoleonic art of war. Both men had prior experience in military operations preceding the Battle of Labadieville-Mouton at Shiloh; Weitzel in the expedition to capture New Orleans and Baton Rouge. Both men had previously exhibited the utmost of professionalism in subordinate command and the potential, at least, for independent command. Both Weitzel and Mouton planned a campaign in the autumn of 1862 based on the Jominian school of thought and attempted, at least, to carry out their campaign based on the known tactics of the day using the infantry, cavalry, and artillery units available to them. ${ }^{12}$

Godfrey Weitzel, of German ancestry, was born in Cincinnati, Ohio in 1835.He graduated from the United States Military Academy in 1855 ranking 2nd in his class. For four years, he served as an engineer assigned to the construction and repair of Forts St. Philip and Jackson guarding the approaches to New Orleans. In part, because of his knowledge of the lower Mississippi River, Weitzel served as chief engineer of Major General Benjamin Butler's expedition to capture these forts in April and Baton Rouge in August 1862. ${ }^{13}$

Alfred Mouton, of French Acadian ancestry, was born in Opelousas, Louisiana in 1829. He graduated from the U.S. Military Academy in 1850 ranking 38th in his class, but shortly thereafter resigned his commission. As a civilian, Mouton served as a planter, a railroad engineer, and as Brigadier General of Louisiana militia. In April 1862, after having reenlisted into Confederate service, Mouton demonstrated exceptional bravery on the battlefield while leading the 18th Louisiana Infantry Regiment at Shiloh where he suffered a wound to his left eye. $^{14}$

A commander in battle can take one of two positions - the offensive or the defensive, or a combination of both. The advantage of the offense is in having the initiative, and choosing the place and time in which to strike the enemy either in the front, flank, or rear. Both Clausewitz and Jomini spoke of the moral advantage of the offensive or the offensive spirit. Hans Delbruck, a preeminent German military historian of the nineteenth century, described it as the "moral lift of the attack" that drives the attackers forward. The disadvantage of the offensive is in having to overcome the disordering and demoralizing effect caused by natural or man-made obstructions and the deadly fire of the enemy's muskets and artillery when traversing the battleground. A second disadvantage of the offensive is that it can itself be counter-attacked in front, flank, and rear. ${ }^{15}$

The advantage of the defense is in choice of the battlefield and exploitation of terrain and firearms. The defensive commander is able to select suitable ground for cover and concealment of one's own forces while leaving a clear line of sight and line of fire of the approaching enemy. The topography can be chosen to secure one's own flanks with natural or artificial obstacles, forcing the enemy to attack in front. Infantry and artillery weapons can then be deployed to insure effective kill zones. Most importantly, the defensive gives the commander the ability to take the offensive when the opportunity presents itself, or to withdraw down a previously chosen unobstructed line of retreat if the battle takes a turn for the worse. The disadvantage is in not having the initiative, at least initially, or the offensive spirit. A passive defense, more often than not, produces a negative outcome. The greatest result is produced by the offense, or the counterattack. ${ }^{16}$

At the Battle of Labadieville, also known as the Battle of Georgia Landing, Godfrey Weitzel took the offensive, while Alfred Mouton took up defensive positions, yet still allowing for the opportunity to go on the

\footnotetext{
12 Warner, Generals in Blue, 548-549; Warner, Generals in Gray, 222-223.

13 Warner, Generals in Blue, 548; Winters, The Civil War in Louisiana, 100, 123.

14 Warner, Generals in Gray, 222-223; Arceneaux, Acadian General, 16-25, 48-53.

15 Clausewitz, On War, 37; Jomini, The Art of War, 163-169; Delbruck, The Dawn of Modern Warfare, $434-435$ (quote).

16 Jomini, The Art of War, 164-169; Delbruck, Dawn of Modern Warfare, 434-435.
} 
offensive at the appropriate time. At stake for the commanders was the Lafourche District. Lying directly southwest of New Orleans between the Mississippi River and the Atchafalaya Basin, the Lafourche District was a region of strategic, demographic, and economic importance to both sides. The Labadieville battlefield lay at the heart of the region intersected by Bayou Lafourche, a waterway of approximately fifty meters wide that flowed out of the Mississippi River at Donaldsonville 25 miles to the north and bisected the Lafourche region on its course to the Gulf of Mexico. ${ }^{17}$

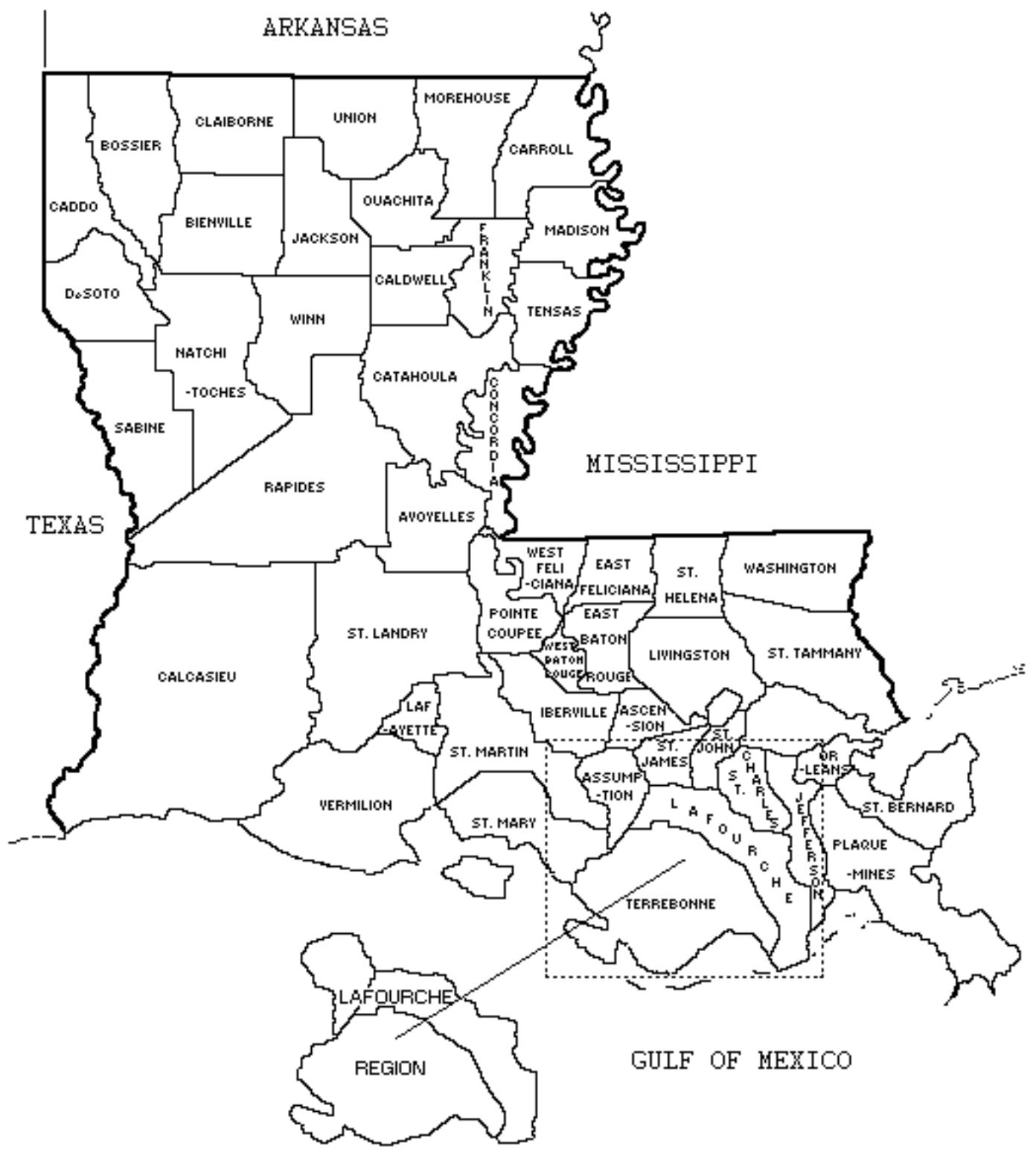

In the autumn of 1862, after an unsuccessful campaign against Vicksburg and the ransacking of Baton Rouge in retreat, Major General Benjamin Butler, the Union commander of the Department of the Gulf, decided upon a campaign to clear out the Lafourche Confederates on his New Orleans flank. Weitzel's army

\footnotetext{
17 Michot, Society at War, 1-2.
} 
was the main part of a three-prong invasion of the Lafourche region held by Mouton's forces. It consisted of four inexperienced albeit well-drilled infantry regiments, two cavalry regiments, two batteries of artillery, and a complement of engineers, signal, and wagon teams - 4,000 men in all. Weitzel was to proceed southward down Bayou Lafourche from Donaldsonville, while a second prong of three infantry regiments was to push westward along the New Orleans, Opelousas, and Great Western Railroad from Algiers, and a flotilla of armored steamers and a regiment of infantry were to proceed northward up the Atchafalaya from the Gulf, all in an attempt to trap the Confederates in the middle. ${ }^{18}$

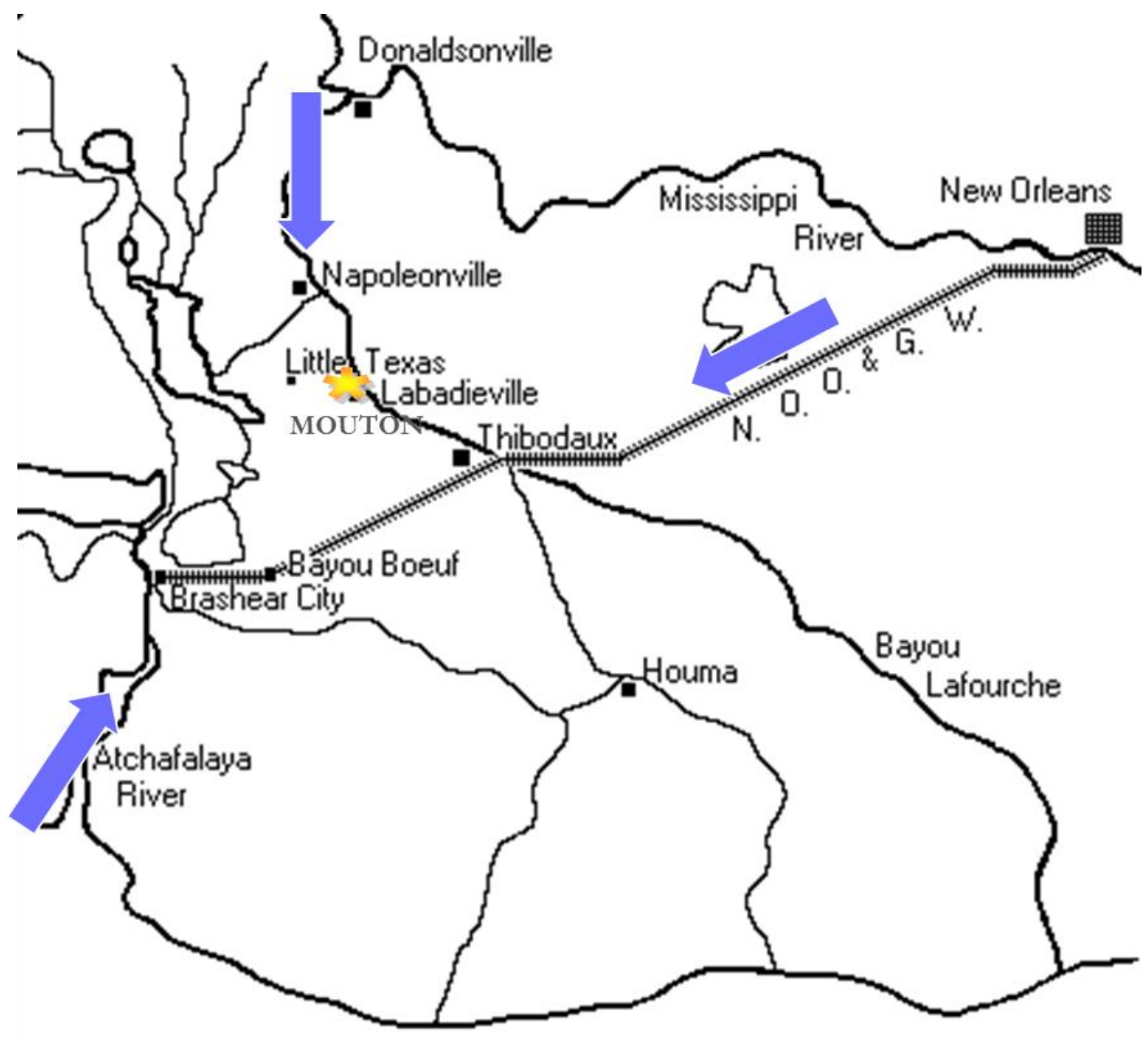

G U L F O F F M E X I C

Mouton had to defend the entire region with only a handful of veteran regulars and untested militia units, approximately 2,300 men, but was still able to concentrate 1,400 of his best soldiers at Labadieville in

\footnotetext{
18 Michot, Society at War, 129-130; Butler, Private and Official Correspondence of Gen. Benjamin F. Butler During the Period of the Civil War, 2:279; U.S. War Department, The War of the Rebellion: A Compilation of the Official Records of the Union and Confederate Armies, ser. 1, part 1, 15:159 (hereinafter cited as Official Records. with all references being to series 1, and, within volumes, part 1).
} 
anticipation of Weitzel's advance. At his disposal at Labadieville were three regiments of infantry, one company of militia, two batteries of artillery, and one regiment of cavalry. For the most part, these men were poorly equipped with smoothbore muskets, and short of ammo and proper clothing. Mouton's advantage, although vastly inferior in numbers and equipment, was in holding the central position, knowing the layout of the land, and in choosing the ground where he planned to make his defense. Weitzel had a numerical superiority but his knowledge of the battlefield area was limited. ${ }^{19}$

Mouton chose his defensive position one mile north of Labadieville at a place known as Georgia Landing. The location was unique in that Bayou Lafourche split the battlefield with a levee, field, and cypress swamp in succession extending outward from the bayou on either side. On the east (left descending) bank, starting on the levee and extending outward into a sugar cane field, Mouton placed Semmes' 1st Confederate Battery, the 33rd Louisiana Infantry Regiment (recently composed from the 10th and 12th LA Battalions), and the Terre Bonne Militia, with a section of the 2nd Louisiana Cavalry on the far right flank, 853 men in all. On the west (right descending) bank, starting on the levee and extending outward along a road ditch and behind a wooden fence, Mouton positioned Ralston's Co. H of the 1st Mississippi Light Artillery, the 24th Louisiana Infantry Regiment, and the 18th Louisiana Infantry Regiment, followed by a section of the 2nd Louisiana Cavalry under Captain Allen Jumel on the far left flank, a total of 539 men. The 18th LA and 24 LA were veterans of Shiloh, as was the 12th LA Battalion. Semmes' Battery had distinguished itself at the Battle of Baton Rouge in August. The 10th LA Battalion, Terre Bonne Militia, and 2nd LA Cavalry each had skirmished with the enemy in the prior months at Raceland, Houma, and Donaldsonville respectively. Mouton's army was small, but battle-tested. ${ }^{20}$

Mouton did not keep a reserve; however, one mile to his rear was a pontoon bridge at Labadieville that he could use to reinforce either side with troops from the opposite bank. In essence, Mouton had achieved the classic central position of interior lines by causing the Union forces to be split while his own Confederate troops could be united through a rear bridge. The problem was in that any advance or withdrawal of troops would be hindered by the thick sugar cane fields that stretched to the rear of Mouton's east bank forces, and a swampy wooded marais that lay to the rear of his west bank forces. Only a narrow levee dirt road parallel to the bayou on both sides offered an unobstructed route to and from Labadieville. ${ }^{21}$

Mouton had accounted for the terrain, but he had not accounted for some of the possible frictions in war. Mouton had been suffering from a severe case of rheumatism, and positioned himself not at the front lines, but at Labadieville a mile to the rear to recover, but possibly to better coordinate the two wings of his small army. In addition, he had recent morale issues with the men of the previous 10th and 12th LA Battalions, which resented losing their independent battalion status when they were consolidated into the 33rd LA. To make matters worse, the region had been experiencing unusually cold weather. Because of the cold and humidity, Mouton's rheumatism had been flaring up, and the gunpowder of his men would be less reliable unlike that of the Union troops who were issued standard leather cartridge boxes. Mouton's poorly-clothed and blanket-less soldiers passed a sleepless chilly night in line of battle. On the morning of the battle and for the several days prior, the morning ground was covered in a white blanket of frost. Their counterparts, on the other hand, were

\footnotetext{
19 Michot, Society at War, 134-135; Official Records, 15:174-178.

${ }^{20}$ Michot, Society at War, 134-135; Official Records, 15:174-178; Jenkins, Diary of the 18th Louisiana Infantry Regiment, 27 October 1862; Bergeron, Guide to Louisiana Confederate Military Units, 1861-1865, 19, 42, 118, 131,163, 165.

${ }^{21}$ Michot, Society at War, 135; Frazier, Fire in the Cane Field, 192.
} 
well-equipped with woolen uniforms, blankets, and tenting material. ${ }^{22}$

Battle came on 27 October 1862.Weitzel's main force, comprising approximately 2,400 men, was on the east (left descending) bank. In line of battle, he deployed the 13thConnecticut and 75th New York infantry regiments supported by Thompson's 1st Maine and Carruth's 6th Massachusetts artillery batteries. The 12th Connecticut and three companies of the 1st Louisiana Cavalry (Union) were held in reserve accompanied by a signal section, an engineer crew of convalescents, and the baggage train. On the west (right descending) bank, approximately 1,000 men, were only the 8th New Hampshire Infantry Regiment, Perkins' Troop C of the 2nd Massachusetts Cavalry, and a baggage train in the rear. The initiative was on the Union side, but the progress of the forward units was disrupted by the dense sugar cane fields 10 feet high intersected by deep drainage ditches on east bank, and tall grass, thorn thickets, and fence posts that fronted the Confederate position for several hundred yards on the west bank, testing the offensive spirit of even the most ardent soldiers in Weitzel's command. ${ }^{23}$

Weitzel held a 3-1 advantage on the east bank and a 2-1 advantage on the west bank. Facing such odds, Mouton had little hope of stopping the Union advance fighting a static defense. Napoleonic tactics dictated a concentration of forces against a critical point in the enemy line. The isolation of the 8th New Hampshire on the west bank and the more favorable ratio of Confederate to Union troops presented that opportunity. The unfolding of events demonstrates that Mouton attempted to reinforce his left wing with elements of his right wing. He could then seize the initiative and fall upon the Union right flank and rear. If Weitzel's right wing could be smashed, and his line of communication/retreat back to Donaldsonville threatened, then this may have been enough to convince Weitzel to retreat.

Weitzel, with an inability to out flank Mouton's defensive positions, intended to press forth an advance in traditional Civil War line of battle fashion, relying upon his weight in numbers and firepower to uproot the enemy. First, the 8th New Hampshire on the west bank, advancing more rapidly than Weitzel's east bank forces, made the initial contact with the enemy; and despite a courageous effort, was repelled with heavy losses by the firepower of Ralston's cannons and veteran muskets of the 18th and 24th Louisiana. While the 8th New Hampshire's advance was being checked and forced to fall back, Weitzel's east bank forces came into contact with the 33rd Louisiana and the Terre Bonne militia which fired sporadically into the Union ranks, then unexpectedly withdrew towards Labadieville. ${ }^{24}$

Sensing a ruse of some sort, and with his signal men wig-wagging messages that the Confederates were in force on the west bank, Weitzel acted swiftly and decisively. He ordered two large flatboats that he brought in tow to be thrown across the bayou into a make-shift pontoon bridge, and the river levee to be cut by the muscle of African laborers to effect the passage of the artillery. Without hesitating, he ordered the withdrawal of the front line units (approximately half a mile or more to the rear) and prepared to cross his 12th Connecticut reserves followed by the 13th Connecticut and the 6th Massachusetts Battery, once the pontoons had been aligned and planked. The 75th New York and 1st Maine Battery were to be held in reserve to protect the bridgehead, wagon train, and line of communications/retreat back to Donaldsonville. ${ }^{25}$

22 Michot, Society at War, 137; Frazier, Fire in the Cane Field, 193; Bergeron, "The Generalship of Alfred Mouton," $178-179$.

23 Michot, Society at War, 132-135; Official Records, 15:166-168; Stanyan, A History of the Eighth Regiment of New Hampshire Volunteers, 140-142.

${ }^{24}$ Michot, Society at War, 136-137; Sprague, History of the 13th Infantry Regiment of Connecticut Volunteers During the Great Rebellion, 82-86; Bearss, "The Civil War Comes to the Lafourche," 114-115.

${ }^{25}$ Michot, Society at War, 137; Official Records, 15:173-174. 


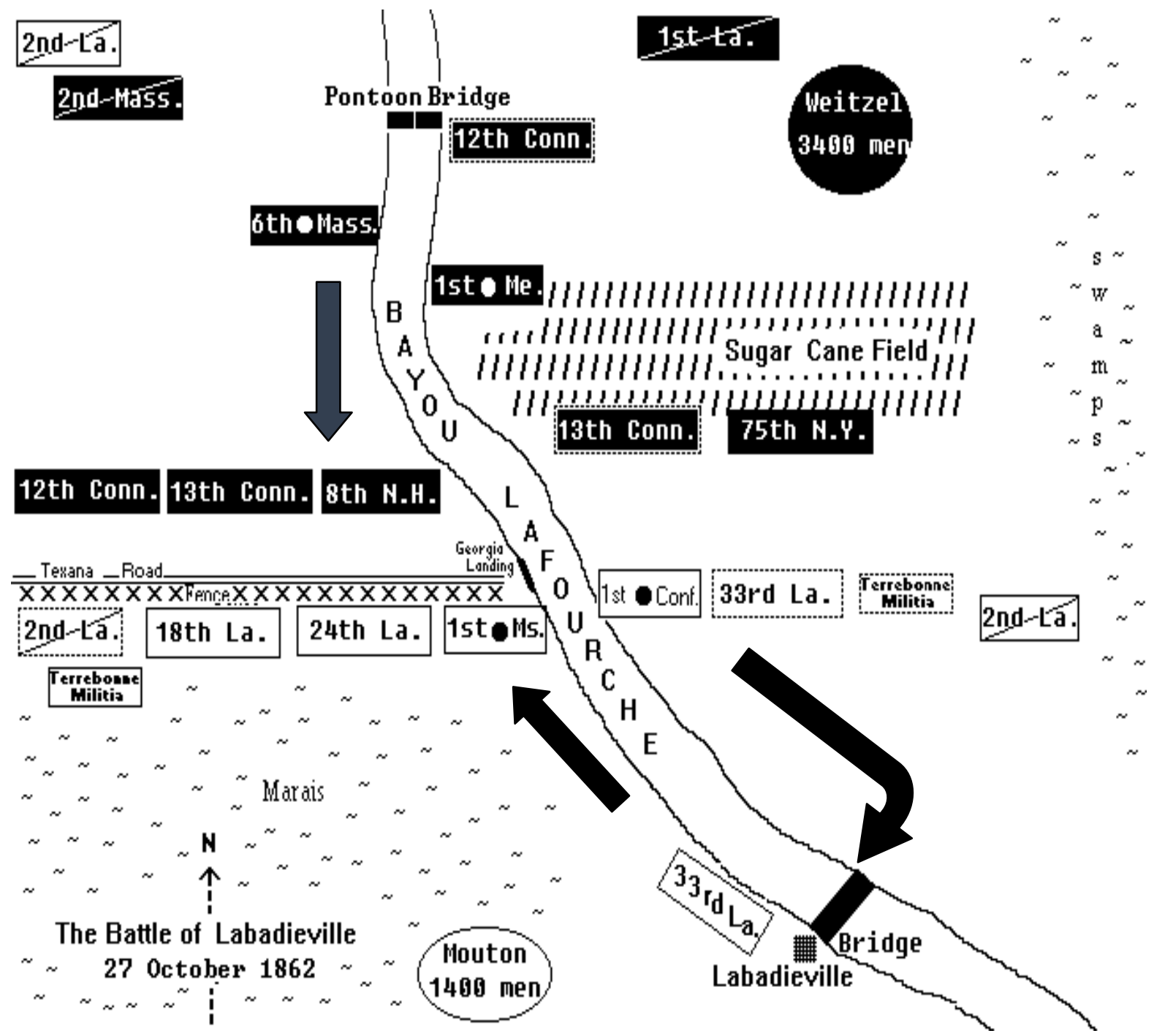

Once securely across the bayou, Weitzel rallied the 8th New Hampshire and threw them, the 13th Connecticut, and the 12th Connecticut into battle line for a renewed advance. The two Union artillery batteries commenced counter-battery fire in support from both sides of the bayou. The Union line once again advanced methodically through the weeds, thrones, fence posts, and deadly fire from a still hidden enemy. Occasionally, the Union forces would go to the ground to avoid a volley of lead, but would quickly return to an upright position, dress ranks, and proceed forward. ${ }^{26}$

At some point during the Union advance, the Terrebonne Militia, having traveled a minimum of two miles from the east to west bank, appeared out on the far Confederate left, fired a volley into the right approaching flank of the 12th Connecticut, and withdrew. Elements of the 33rd LA may not have been far behind since Mouton indicated in his official report that portions of his east bank infantry had been thrown over to the west bank. Earlier, the 2nd LA Cavalry, by a circuitous route, fell upon the wagon train in the immediate rear of the Weitzel's west bank forces, but were soon driven off by the 2nd Massachusetts Cavalry. After nearly an hour of

\footnotetext{
26 Jenkins, Diary of the 18th Louisiana Infantry Regiment, 27 October 1862; Michot, Society at War, 137; Frazier, Fire in the Cane Field, 201-203; Official Records, 15:173-174.
} 
continuous firing, Ralston's battery fell silent. With its commander severely wounded and ammunition depleted, the 64-man unit limbered its guns and pulled back to the rear. Without the support of the cannons, and with their own ammunition probably running low or depleted, the Confederate infantry now withdrew pell-mell towards the rear either through the rear marais or down the now obstructed line of retreat. Weitzel sent the 2nd Massachusetts Cavalry and the 6th Massachusetts Artillery in pursuit but made no major effort to engage the Confederates which made a second defensive stand four miles to the south. In the days that followed, Mouton evacuated the region bringing an end to the campaign. ${ }^{27}$

Why did the Union win? Weitzel had superiority in troops, but not overwhelming at all points at all times. Weitzel seized the initiative and took the offensive giving him a moral advantage. Because of the enclosing swamps and cane fields, and his limited knowledge of the terrain, he could not choose the place where he would attack the enemy. By default, Weitzel committed to a simple yet somewhat bloody frontal assault instead of maneuvering against Mouton's flanks and rear. He maintained excellent command and control of his east bank forces, but temporarily had none over his west bank troops which almost spelled disaster. Through good intelligence, sound preparation, and quick decision-making, Weitzel was able to reverse the initial setback to his west bank forces and re-establish command and control. He manufactured a make-shift pontoon bridge and used it to mass an overwhelming force against the enemy's main effort while maintaining adequate security on the east bank. After the Confederate withdrawal, Weitzel pursued but did not press a renewed attack easily allowing for the beaten Confederates to escape.

Could the Confederates have won? Well, yes. Mouton had choice of the battlefield. He exploited the terrain and available firepower to his advantage using cover and concealment of his troops while establishing a clear line of fire against the enemy. His flanks were secured and he forced the enemy to do what he wanted them to do-split their forces and attack his front. He had a good plan to smash Weitzel's west bank force using firepower, concentration of force, and maneuver; and if properly executed, Mouton may have been able to prevent the Union army from massing onto the west bank. The 8th New Hampshire was beaten, and Weitzel was still many minutes away from completing his crossing. A counter-charge by the veteran 18th LA and 24th LA, coordinated with the 2nd LA Cavalry's attack on the Union rear, and coinciding with the arrival of reinforcements from the east bank (as the Terre Bonne Militia demonstrated)may have made the difference against green and unproven troops. Ralston's Battery still had a complement of ammunition at this time that could have been used to deadly effect in a forward position against any massing of troops attempting a crossing. Even still, the timely arrival of Semmes' east bank Battery replacing Ralston's ammo-depleted west bank battery late in the battle may have discouraged a pre-mature Confederate withdrawal.

So why did Mouton lose when he could have won? In battle and retreat, Mouton exhibited little in the way of command and control over his troops. Art Bergeron in "The Generalship of Alfred Mouton" heavily criticized the Confederate general for his poor leadership at Labadieville. ${ }^{28}$ Major General Richard Taylor, Confederate commander of the District of Western Louisiana and Mouton's immediate superior, reported that Mouton's failure to unite his east and west bank forces, let along concentrate all available forces in the Lafourche region, were the principal causes of his defeat. ${ }^{29}$ Jomini stated that "the best thing for an army

\footnotetext{
27 Michot, Society at War, 138-139; Frazier, Fire in the Cane Field, 203-204; Official Records, 15:169, 177-178; Jenkins, Diary of the 18th Louisiana Infantry Regiment, 27 October 1862; DeForest, A Volunteer's Adventures, 65-67.

${ }^{28}$ Bergeron, "The Generalship of Alfred Mouton," 179-180.

29 Taylor, Destruction and Reconstruction, 128.
} 
standing on the defensive is to know how to take the offensive at a proper time, and to take it. ${ }^{, 30}$ Clausewitz discussed the necessity of the commander to project will-power, resolution, self-confidence, and bold initiative in order to be victorious. These traits were largely missing in Mouton on 27 October 1862.Why? An examination of this question takes us back to Clausewitz and friction in war-climate, disease, and morale.

As an example of friction in war, Clausewitz discussed the unforeseen effects of climate. Weather blurs visibility, disrupts communications, delays reinforcements, causes misfires, and ruins a charge, he wrote. ${ }^{31}$ Paddy Griffith wrote that wintry climate produces a cold wet ground, prevents the soldier from drying off, and makes gunpowder useless if it becomes moist. ${ }^{32}$ Silas Grisamore of the 18th LA recorded that on 25 October 1862, "the weather had been turning cold all day; a sharp, stinging, North wind was blowing furiously," on 26 October, "the ground was white with snow," and that on 27 October, "the sugar cane was frozen to the ground." 33 Josephine Nicholls Pugh of Woodlawn Plantation near the battlefield penned the night of the 25-26 October was sleepless because "the wind increased in violence, blowing a cold Nor-Wester," then noted the "poorly clad" condition of the Southern boys. ${ }^{34}$ Because of the climate, Mouton's men were cold, damp, and miserable. On a positive note, the severe storm and the strong north wind delayed the Union steamers arrival at Berwick Bay on the Atchafalaya until after Mouton had evacuated the region, denying Weitzel of a decisive campaign victory. ${ }^{35}$

Disease was the cause of the vast majority of Civil War casualties, and yet another friction in war at the Battle of Labadieville. In the Lafourche Region, disease was responsible for killing an equal number of civilians and soldiers during the war years. ${ }^{36}$ One of the most common diseases inflicting Civil War soldier were rheumatic diseases. ${ }^{37}$ Rheumatism is the inflammation of the joints, muscles, or tissue. Historically, rheumatism was a reference to any inflammatory disorder. ${ }^{38}$ The effects can be debilitating causing pain, swelling, and stiffness in the joints and muscle weakness. The individual has difficulty performing routine functions such as dressing or combing hair. The person cannot grip objects, walk, sit, or bend over without extreme pain in severe cases. ${ }^{39}$ Mouton after the battle of Shiloh was diagnosed with erysipelas, an inflammation of the skin or tissue. ${ }^{40}$ At the Battle of Labadieville, Mouton was suffering from a severe case of rheumatism. The attack was physically debilitating to the point that the Rebel General was unable to go to the front. ${ }^{41}$ In effect, Mouton had little control over his troops or impact on the course of the battle, and failed to relieve himself from command. To what extent did disease affect Mouton's men or that of the Union soldiers can only be guesswork; however, it can be assumed that a certain percentage on both sides were probably suffering from various ailments such as dysentery and malaria. ${ }^{42}$ Interestingly, climate and health have been

\footnotetext{
30 Jomini, The Art of War, 167.

${ }^{31}$ Clausewitz, On War, 120.

${ }^{32}$ Griffith, Battle Tactics of the Civil War, 120.

33 Bergeron, The Civil War Reminiscences of Major Silas T. Grisamore, C.S.A., 97-98.

${ }^{34}$ Pugh, "Essay from Woodlawn, October 1862," 16

35 Butler, Correspondence of Butler, 2:430; Official Records, 15:183.

${ }^{36}$ Michot, Society at War, 270.

37 Bollet, NCBI PubMed, www.ncbi.nlm.nih.gov see also, Medical and Surgical History of the War of the Rebellion. Medical History, pt. I, vol. I, 637-639.

38 Mandal, www.news-medical.net

39 WebMD, www.webmd.com

40 Bergeron, "The Generalship of Alfred Mouton," 177; Aberth, The First Horseman, 2.

41 Bergeron, Reminiscences of Silas T. Grisamore, 98; Bergeron, "The Generalship of Alfred Mouton," 179.

42 The 75th New York Infantry Regiment had reportedly been suffering from the effects of malaria or the "swamp fever" just prior to the Lafourche expedition. See Official Records, 15:159.
} 
interconnected. Studies on Union amputees indicate that pain began as barometric pressure fell and humidity rose, such as in an approaching storm. ${ }^{43}$ This also can apply to rheumatism. Two days prior to the Battle of Labadieville, there was a severe storm that caused a drop in pressure and a rise in humidity, and apparently an unexpected chronic outbreak of Mouton's debilitating disease.

Clausewitz spoke extensively about the effects of morale on battle, or what he termed moral factors. "The effects of physical and psychological factors ... can no more be omitted from the theory of the art of war than can any of the other components of war." "44 "The realm of suffering, confusion, exhaustion and fear" were all factors that combined to create friction. ${ }^{45}$ Jomini said, "it is the morale of the armies ... more than anything else, which makes victories ..." Morale issues can be caused by any number of factors such as improper equipment, shelter, and clothing; miserable weather conditions and illness; disputes over pay and discipline; exhaustion; and finally poor leadership. Mouton's army on the eve of the Battle of Labadieville was suffering from most if not all of these issues, which more than likely affected performance. The morale of the 33rd LA on the east bank in particular was questionable due to a recent consolidation of two antagonistic battalions - the 10th and 12th LA. Reports have it that many of these men ran without firing a shot although this fleeing may have occurred during the pursuit phase of the battle. ${ }^{47}$

In conclusion, the Battle of Labadieville is an excellent case study of two Jominian-trained Civil War commanders attempting to apply Napoleonic tactics on the battlefield. Strongly influential of the results of battle were Clausewitzian frictions in war. Effective leadership could have reversed many of these factors. A good commander can instill in the most unresponsive soldier a sense of mission, enthusiasm, and fighting spirit to counteract morale issues. Proper planning can oftentimes reduce the ill-effects of weather, if anticipated. Disease was debilitating in most pre-twentieth century conflicts. This was true not only to the men of the line, but in this case to the Confederate general himself who should have relinquished command. Effective leadership was present at the Battle of Labadieville — on the Union side. The Confederate command, however, was largely ineffective in the execution of Jominian tactics and élan. Mouton had been out-witted and out-classed largely because of his illness, the climate, and the morale of his troops. Clausewitz said, "the good general must know friction in order to overcome it ..."

\section{References}

Aberth, J. (2007). The First Horseman: Disease in Human History. Upper Saddle River, NJ: Pearson/PrenticeHall.

Arceneaux, W. (1981). Acadian General: Alfred Mouton and the Civil War. Lafayette, LA: The Center for Louisiana Studies.

Bearss, E. C. (1966). The Civil War comes to the Lafourche. Louisiana Studies, 5.

Bergeron, A. W., Jr., (Ed.). (1993). The Civil War Reminiscences of Major Silas T. Grisamore, C.S.A. Baton Rouge, LA: Louisiana State University Press.

Bergeron, A. W., Jr. (2002). The general ship of Alfred Mouton.In L. L. Hewitt \& A. W. Bergeron (Eds.), Louisianians in the Civil War. Columbia: University of Missouri Press.

Bergeron, A. W., Jr. (1989). Guide to Louisiana Confederate Military Units, 1861-1865. Baton Rouge, LA: LSU Press.

Bollet, A. J. NCBI PubMed, www.ncbi.nlm.nih.gov

\footnotetext{
${ }^{43}$ www.intellicast.com

${ }^{44}$ Clausewitz, On War, 184-185.

45 Howard, Clausewitz, 25.

46 Jomini, The Art of War, 162-163.

47 Bergeron, Reminiscences of Silas T. Grisamore, 98-99 (footnote \#16).

${ }^{48}$ Clausewitz, On War, 120.
} 
Bruce, R., Dickie, I., Kiley, K., Pavkovic, M., \& Schneid, F. (2008). Fighting Techniques of the Napoleonic Age, 1792-1815. New York: St. Martin's Press.

Butler, B. F. (1917). Private and Official Correspondence of Gen. Benjamin F. Butler During the Period of the Civil War. Vol. 5. Norwood, MA.

Clausewitz, C.V. (1976). On War. Edited and translated by H. Michaeland P. Peter Princeton, NJ: Princeton University Press.

DeForest, J. W. (1946). A Volunteer's Adventures: A Union Captain's Record of the Civil War. New Haven, CT: Yale University Press.

Delbruck, H. (1985). The Dawn of Modern Warfare: History of the Art of War. Vol. IV. Lincoln, NE: University of Nebraska Press.

Frazier, D. S. (2009). Fire in the Cane Field: The Federal Invasion of Louisiana and Texas, January 1861-January 1863. Buffalo Gap, TX: State House Press.

Griffith, P. (1986). Battle in the Civil War: Generalship and Tactics in America, 1861-65. Fieldhead, England: Fieldbooks.

Griffith, P. (1987, 1989). Battle Tactics of the Civil War. New Haven, CT: Yale University Press.

Hardee, W. J. (1861). Hardee's Rifle and Light Infantry Tactics.

Howard, M. (1983). Clausewitz. Oxford, England: Oxford University Press.

Jenkins, H. N. Diary of the 18th Louisiana Infantry Regiment, 1861-1865 (unpublished).

Jomini, A. H. B. D. (1960). The Art of War. Translated by G. H. Mendell and W. P. Craighill. Philadelphia: Lippincott, J. B., 1862; reprinted, Westport, CT: Greenwood Press.

Leonard, R. A. (Ed.). (1967). A Short Guide to Clausewitz On War. New York: G. P. Putnam's Sons.

Mandal Ananya, M. D. www.news-medical.net

Medical and Surgical History of the War of the Rebellion. Medical History. Washington, D.C.: GPO, 1870. Part I, Vol. I.

Michot, S. S. (1994). Society at War: Sectionalism, Secession, and Civil War in Louisiana's Lafourche Region. Ph.D. diss., Mississippi State University.

Preston, R., Roland, A., and Wise, S. (1956, 1991).Men in Arms: A History of Warfare and Its Interrelationships with Western Society. Orlando, FL: Harcourt Brace Jovanovich.

Pugh, J. N. (2000). Essay from Woodlawn, October 1862.In E. C. Plaisance (Ed.), Louisiana Soldiers in the Civil War. Cut Off, LA: Bayou Publications, Lafourche Parish Public Library, Thibodaux, LA.

Ross, S. T. (1985). Napoleon and Maneuver Warfare. In The Harmon Memorial Lectures in Military History. Colorado Springs, CO: United States Air Force Academy.

Sprague, H. B. (1867). History of the 13th Infantry Regiment of Connecticut Volunteers During the Great Rebellion. Hartford, CT: Case, Lackwood.

Stanyan, J. M. (1892). A History of the Eighth Regiment of New Hampshire Volunteers. Concord, NH: Ira C. Evans.

Taylor, R. (1879). Destruction and Reconstruction. New York: Bantam Books.

U.S. War Department. The War of the Rebellion: A Compilation of the Official Records of the Union and Confederate Armies, 128 parts in 70 vols. Washington, D.C.: 1880-1901. Series 1, Part 1 (hereinafter cited as Official Records with all references being to Series 1, and, within volumes, Part 1).

Warner, E. J. (1964, 1992). Generals in Blue: Lives of the Union Commanders. Baton Rouge, LA: LSU Press.

Warner, E. J. (1959, 1987). Generals in Gray: Lives of the Confederate Commanders. Baton Rouge, LA LSU Press. WebMD, www.webmd.com

Winters, J. D. (1963). The Civil War in Louisiana. Baton Rouge, LA: LSU Press.www.intellicast.com 